\title{
The effects of different factors influencing commuterline in Indonesia
}

\author{
Dede Jajang Suyaman $^{a^{*} \text {, Nelly Martini }}{ }^{\mathrm{a}}$, Asep Muslihat ${ }^{\mathrm{a}}$ and Rahmat Jaelania
}

\begin{tabular}{l}
${ }^{a}$ Universitas Singaperbangsa Karawan \\
\hline C H R O N I C L E \\
\hline Article history: \\
Received: June 18, 2021 \\
Received in revised format: June \\
29,2021 \\
Accepted: August 4, 2021 \\
Available online: August 4, 2021 \\
\hline Keywords: \\
Costumer Behavior \\
Electric Rail Train \\
Transportation \\
\end{tabular}

donesia

\section{A B S T R A C T}

\begin{abstract}
Commuterline plays an important role for transportation planning in Indonesia, and it is essential to learn more on how to motivate people to actively use this public transportation facility. This paper presents an empirical investigation to explore different factors influencing the use of this publica transportation facility. The proposed study develops a questionnaire in Likert scale and distributes it among 374 people who had good experience of using commuterline in their daily lives. The questionnaire is designed to learn the effects of environmental, individual, consumer resources and psychological factors. Using some statistical techniques, the study has determined that psychological factors are the most important elements influencing consumer behavior to use this public transportation followed by consumer resources, product knowledge and individual characteristics.
\end{abstract}

\section{Introduction}

C 2022 by the authors; licensee Growing Science, Canada.

The KRL Commuterline is managed by PT Kereta Commuter Indonesia or KCI, previously known as PT Kereta Api Indonesia Commuter Jabodetabek which is a subsidiary of PT Kereta Api Indonesia (Persero). The KRL Commuter Line in one trip consists of 8 to 12 series of trains. Each train car can carry up to 250 passengers, in other words in one trip the KRL Commuterline can carry 3000 passengers. Carrying the slogan Best Choice for Urban Transport, the Indonesian Commuter Train has a target of serving 1.2 million passengers per day by 2019 with 1,450 train units. Based on the 2017 KCI report, using 792 train units, the KRL Commuterline can carry 315,853,991 passengers with an average number of passengers per day reaching 993,804 people, even based on the latest data from its official website www.krl.co.id KRL Commuterline until June 2018 carrying an average of $1,001,438$ passengers per day.

Commuterline plays an important role for transportation planning in Indonesia, and it is essential to learn more on how to motivate people to actively use this public transportation facility. This type of facility has been widely used in the world as public transportation to help cities reduce traffic jams, travel costs, etc. There are literally several works dedicated to understand the effects of different factors on product development in such areas (Ery1lmaz \& Tezcan, 2019). Aisyah et al. (2019) performed a survey to determine the effects of service quality and price on attracting more consumers. Levyda and Ismi (2020) detected the most efficient advertising planning compared with different locations and to find out the behavior of commuter line passengers. They reported that the effectiveness of each location on the commuterline was different, and the most effective advertising location was the hanging alley. Zubair et al. (2019) performed an empirical survey to learn more about the effects of consumer's personal characteristics on using commuterline in Indonesia. Katili et al. (2018) studied the impact of commuterline train's service quality on customer satisfaction and customer loyalty. Adi (2020) also tried to learn on how consumer look for information on a train during the trip interruption.

* Corresponding author.

E-mail address: djsuyaman.unsika@gmail.com (D. J. Suyaman)

(C) 2022 by the authors; licensee Growing Science, Canada. doi: $10.5267 /$ j.ijdns.2021.8.005 
Congestion is an inevitable issue in any populated country in line with the increasing number of vehicles which are increasing daily and human activities, which are getting denser, in the modern era. Congestion can occur in various countries, both developed and developing countries such as Indonesia. According to an Inrix Research report in 2017, Indonesia is the second most congested country in the world after Thailand. The average number of hours of congestion in Indonesia happens for 51 hours per year. In addition to Inrix Research, the Tom Tom Traffic Index releases the most congested cities in the world. The capital city of Indonesia, Jakarta is ranked 7th as the most congested city in the world out of the 403 families studied with the congestion rate in Jakarta reaching $53 \%$ every day. This is certainly a big homework for the city of Jakarta, which is the city with the largest area in Indonesia. Based on a report from the Central Statistics Agency of DKI Jakarta Province, Jakarta has an area of $622 \mathrm{Km}^{2}$ with an estimated population of 10,374,235. In addition, there were 18,669,056 vehicles registered in Jakarta in 2016. Most vehicles in Jakarta include motorbikes and cars and passengers with 16,836,597 vehicles. The number of existing vehicles and its citizens, which number more than 10 million people, have their respective mobility to carry out various activities, therefore it is not surprising that Jakarta is the city with the highest level of congestion in Indonesia.

\section{The proposed study}

This paper presents an empirical investigation to explore different factors influencing the use of this publica transportation facility. The proposed study develops a questionnaire in Likert scale and distributes it among some people who had good experience of using commuterline in their daily lives. The questionnaire is designed to learn the effects of environmental, individual, consumer resources and psychological factors. The questionnaire was first passed to some expert for validation and the reliability of the questionnaire was measured using Cronbach alpha. The sample size is determined by a method suggested by Sugiyono (2017) as follows,

$s=\frac{\lambda^{2} \cdot N \cdot P \cdot Q}{d^{2}(N-1)+\lambda^{2} \cdot P \cdot Q}$

where

$\mathrm{S}=$ Number of samples

$\lambda^{2}=$ Chi Square whose value depends on the degree of freedom and the degree of error. For 1 degree of freedom and $5 \%$ error (confidence level) the value of Chi Square $=3.841$.

$\mathrm{d}=$ The difference between the population mean and the sample mean (sampling error $/$ sample precision) $=5 \%=0.05$

$\mathrm{P}=\mathrm{Q}=0.5$

$\mathrm{N}=$ Total population.

For the implementation of the proposed study, we have

$$
s=\frac{3,841 \times 13,870 \times 0.5 \times 0.5}{0.05^{2} \times(13,870-1)+3.841 \times 0.5 \times 0.5}=373.7786
$$

The implementation of the proposed study distributes 374 questionnaires among randomly selected travelers who had some experiences on using this type of facility. The study uses factor analysis to determine the influencing factors on consumers to choose such facilities for traveling. Table 1 summarizes the results of our survey. According to our survey, the following five factors are extracted:

\section{Factor 1: Psychological Process Factors}

The first factor is named as informational and psychological processing factor. Information processing and psychological factors consist of retention, understanding of information, consumer attitudes, vicarious learning, purchasing knowledge, usage knowledge, and consumer motivation with a score of $27.692 \% \%$ of variance. This means that information processing and psychological factors are influencing consumers to use KRL Commuter Lines by $27.692 \%$.

\section{Factor 2: Situation Factors and Consumer Resources}

The second factor is named as the situation factor and consumer resources. Factors and consumer resources consist of usage situations, purchasing situations, economic resources, temporal resources, cognitive resources with a score of approximately nine percent.

\section{Factor 3: Product Knowledge Factor and Individual Characteristics}

The third factor is named as Product Knowledge and Individual Characteristics. This factor consists of product knowledge, lifestyle, work, and consumer involvement. This factor is taken into account in consumers using the KRL Commuter Line transportation mode with a total score of variance of $9.220 \%$. 
The fourth factor is named as the environmental factor. Environmental factors are taken into account in consumers using the KRL Commuterline transportation mode. Environmental factors consist of culture, subculture, social class, and life cycle stages. Score\% of variance $5.580 \%$

\section{Factor 5: Family Factor}

The fifth factor is named as the family factor. Family factors are considered in consumers using the KRL Commuter Line transportation mode. Family factors consist of parental support, family members, communication situations, and social status $5.343 \%$.

Table 1

The summary of the implementation of factor loading

\begin{tabular}{|c|c|c|c|c|c|}
\hline $\mathrm{N}$ & Factor & Indicator & Factor Value & $\%$ of Variance & Cumulative $\%$ \\
\hline \multirow[t]{7}{*}{1} & Information and & Information Process and Psychological Retention & 0.785 & \multirow{7}{*}{27.692} & \multirow[t]{7}{*}{27.692} \\
\hline & \multirow{6}{*}{$\begin{array}{l}\text { Psychological } \\
\text { Processes }\end{array}$} & Understanding of Information & 0.783 & & \\
\hline & & Consumer Attitude & 0.742 & & \\
\hline & & Vicarious Learning & 0.692 & & \\
\hline & & Purchasing Knowledge & 0.668 & & \\
\hline & & Usage Knowledge & 0.638 & & \\
\hline & & Consumer Motivation & 0.601 & & \\
\hline \multirow[t]{5}{*}{2} & \multirow{5}{*}{$\begin{array}{l}\text { Consumer Situa- } \\
\text { tion and Re- } \\
\text { sources }\end{array}$} & Consumer Situation and Resources Use Situation & 0.743 & \multirow[t]{5}{*}{9.220} & \multirow[t]{5}{*}{36.912} \\
\hline & & Purchasing Situation & 0.678 & & \\
\hline & & Economic Resources & 0.548 & & \\
\hline & & Temporal Resources & 0.510 & & \\
\hline & & Cognitive Resources & 0.508 & & \\
\hline \multirow[t]{4}{*}{3} & \multirow{4}{*}{$\begin{array}{l}\text { Product } \\
\text { Knowledge and } \\
\text { Individual } \\
\text { Characteristics }\end{array}$} & Product Knowledge and Individual Characteris- & 0.713 & \multirow[t]{4}{*}{6.293} & \multirow[t]{4}{*}{43.205} \\
\hline & & Lifestyle & 0.627 & & \\
\hline & & Profession & 0.605 & & \\
\hline & & Get involved in spreading information & 0.490 & & \\
\hline \multirow[t]{4}{*}{4} & \multirow[t]{4}{*}{ Environment } & Cultural Environment & 0.783 & \multirow[t]{4}{*}{5.580} & \multirow[t]{4}{*}{48.785} \\
\hline & & Sub Culture & 0.715 & & \\
\hline & & Social class & 0.563 & & \\
\hline & & Life Cycle Stages & 0.484 & & \\
\hline \multirow[t]{5}{*}{5} & \multirow[t]{5}{*}{ Family } & Family Parental Encouragement & 0.801 & \multirow[t]{5}{*}{5.343} & \multirow[t]{5}{*}{54.128} \\
\hline & & Family members & 0.648 & & \\
\hline & & Communication Situation & 0.480 & & \\
\hline & & Social status & 0.448 & & \\
\hline & & Cognitive Learning & 0.437 & & \\
\hline
\end{tabular}

\section{Conclusion}

From the results of the research conducted, we have learnt more about the factors that influence consumers to use the Commuterline electric train (KRL) mode of KRL Commuter Line users at Manggarai Station and there are two things that researchers can conclude based on the results of this study, namely:

1. There are five groups of factors that influence consumers to use the Commuterline electric train (KRL) on the KRL Commuter Line users at Manggarai Station, namely: psychological process factors, situation factors and consumer resources, product knowledge factors and individual characteristics, environment, and family factors. The factors obtained in this study affect consumers to use the Commuter Line electric train (KRL) on the Commuter Line KRL users at Manggarai Station are in the "Quite Important" criteria because they have a percentage of influence of 54.128\%. This means that all the factors formed are considered quite important by KRL Commuter Line users.

2. The most dominant factor influencing consumers to use the Commuter Line electric train (KRL) on the KRL Commuter Line users at Manggarai Station is the psychological process factor that affects $27.692 \%$ or in other words the psychological process factor affects $51.160 \%$, which is greater than the four factors. other.

Based on the results of the research carried out on this occasion the researchers will give a few suggestions which are expected to be input and material for consideration for companies and the development of knowledge for future researchers.

Suggestions for companies that can be considered and become input and material for consideration by companies that are for the progress of the company itself. Based on the results of this study, the authors provide suggestions to PT. The Indonesian Commuter Train as the operator of the Lined Commuter KRL and Manggarai Station as a place for the commuter Line KRL passengers to ride and fall. The suggestions that can be given to PT. The Indonesian Commuter Train is to maintain good service standards by increasing the number of trips during peak hours as well as the passenger information system available 
in each series of travel trains so that users with disabilities can get the same information as other passengers which affect the user's psychological process of using this mode of transportation. with the slogan best choice for urban transport. The next suggestion is for the KRL Commuter Line to further intensify a promotion related to the family in order to increase family influence using the KRL Commuter Line, such as "celebrating family holidays is more fun with the KRL Commuter Line" and so on.

Suggestions for PT. Kereta Api Indonesia, in this case Manggarai Station, to continue to improve its performance in serving its passengers and improve supporting facilities at the station, especially those related to facilities that are friendly to people with disabilities and reduce the platform distance to trains that are long and uneven.

\section{References}

Adi, W. (2020). Simplified Social Mediated Crisis Communication Model during Crisis in Indonesia: A Case Study on How Customers of Indonesia Commuter Line Train Company Seek Information on a Train Delay Due to the Double Track Trial on April 12, 2019. KnE Social Sciences, 290-301.

Aisyah, W. U. N., Salim, F., \& Sofyan, M. (2019). The Influence of Service Quality and Price on the Interest of Commuterline KRL Passengers. Ilomata International Journal of Management, 1(1), 13-18.

Eryilmaz, Y., \& Tezcan, H. O. (2019). Towards a compact macroform: commuter line optimization in Istanbul. Transportation Letters, 11(3), 130-145.

Katili, P. B., Fenna, D. S., \& Ummi, N. (2018). The effect of commuter line train's service quality to customer satisfaction and customer loyalty. In First International Conference on Technology and Educational Science. European Alliance for Innovation (EAI).

Levyda, L., \& Ismi, T. N. (2020). Effective Advertising Location in the Commuter Line: Study Cases in Jakarta and Surrounded Cities in Indonesia. The Winners, 21(1), 59-66.

Sugiyono. (2017). Metode Penelitian Bisnis Pendekatan Kuantitatif, Kualitatif,dan R\&D. Bandung: Alfabeta

Zubair, A., Barus, L. S., \& Soemabrata, J. (2019). Passenger behavioral mapping and station facilities design at commuter line train station (Case: Tangerang station, Indonesia). International Journal, 16(58), 151-156.

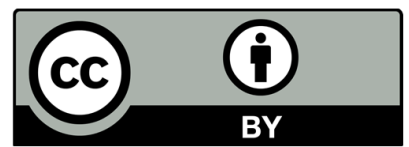

(C) 2022 by the authors; licensee Growing Science, Canada. This is an open access article distributed under the terms and conditions of the Creative Commons Attribution (CC-BY) license (http://creativecommons.org/licenses/by/4.0/). 